\title{
HOME SWEET HOME? WIDE-RANGING MOVEMENTS OF SOCIALLY STABLE RESIDENT DELPHINIDS (GLOBICEPHALA MACRORHYNCHUS)
}

\author{
Filipe Alves*, Anita Alessandrini*,**, Marc Fernandez ${ }^{* * *}$, \\ Karin L. Hartman* \& Ana Dinis*
}

\begin{abstract}
Movement patterns of delphinid populations are generally known to occur within specific geographical areas; with the exception of the killer whale (Orcinus orca). Additionally, knowledge of wide-ranging migrations in these animals are mainly attributed to individual records with limited information on their social structure, residency status or purpose of migration. Here, a comparison of photographic-identification catalogues of short-finned pilot whales (Globicephala macrorhynchus) from the two most isolated archipelagos of the North Atlantic (Madeira and Azores) shows that five well-marked adult animals have made a round-trip movement, of no less than $2000 \mathrm{~km}$. These delphinids belong to the main resident pod in Madeira, where they present long-term site fidelity and were photographed in the Azores during an apparent stop (of at least 10 days), most likely for breeding or feeding purposes. The analysis of the association patterns of these individuals shows that they were sighted together on multiple occasions during the entire study period, suggesting that they are members of a cohesive unit. These findings broaden our understanding on these animals' home ranges and suggest caution when establishing residency status in delphinids.
\end{abstract}

KEYwords: biogeography, individual associations, North Atlantic, photo-identification, site fidelity, temporal social patterns.

¿HOGAR DULCE HOGAR? AMPLIOS RANGOS DE DESPLAZAMIENTO DE DELFÍNIDOS RESIDENTES Y SOCIALMENTE ESTABLES (GLOBICEPHALA MACRORHYNCHUS)

\section{RESUMEN}

Los patrones de movimiento de las poblaciones de delfínidos son generalmente limitados en el espacio, con la excepción de la orca (Orcinus orca). Además, la información sobre las grandes migraciones de estos animales es limitada en relación con la estructura social, estatus de residencia o el propósito de la migración. En el presente trabajo, la comparación de catálogos de fotoidentificación de calderón tropical (Globicephala macrorhynchus) de Madeira y Azores mostró que cinco animales adultos han realizado un viaje de ida y vuelta, de no menos de $2000 \mathrm{~km}$. Estos delfínidos pertenecen a un grupo residente en Madeira, tienen una fidelidad de larga duración y fueron fotografiados en Azores durante una parada aparente, de al menos 10 días, seguramente para la cría y alimentación. El análisis de los patrones de asociación de estos individuos muestra que fueron registrados juntos en múltiples ocasiones durante todo el periodo de estudio, sugiriendo que son miembros de una unidad cohesionada. Estos descubrimientos amplían nuestro entendimiento sobre el rango de distribución y movimiento de estos animales y sugieren cautela al establecer los estatus de residencia de los delfínidos.

Palabras clave: biogeografía, asociaciones individuales, Atlántico Norte, fotoidentificación, fidelidad al sitio, patrones sociales temporales.

DOI: http://doi.org/10.25145/j.SI.2018.01.004

Revista Scientia Insularum, 1; diciembre 2018, pp. 37-49; ISSN: e-2659-6644 


\section{INTRODUCTION}

Knowledge of animals' movement patterns is essential in several areas of ecology, as well as in related sub-disciplines, including global environmental issues and resources management. Nevertheless, obtaining such information can be challenging, especially when targeting wild, unconfined populations, as seen with whales and dolphins (Order Cetacea).

A non-invasive technique based on photographic-identification (Würsig and Würsig 1977) has been successfully used to infer the modal and extreme home ranges and social systems (together with other parameters such as populations' life histories and group dynamics) of naturally marked cetacean populations worldwide (Stone et al. 1990; Whitehead 2001). For example, it showed that single/mother-calf baleen whales perform large-scale seasonal migrations (Robbins et al. 2011), and that stable units of females and immature sperm whales (Physeter macrocephalus) inhabit the tropics/subtropics, with mature males dispersing to higher latitudes (Whitehead et al. 2008). Additionally, it allowed identifying home ranges and characterising populations/ecotypes of distinct social systems (e.g. dynamic or matrilineal) with intra- and inter-annual site fidelity in several delphinid species (Wilson et al. 2004; Foote et al. 2010; Chabanne et al. 2017). Yet, wide-ranging movements of delphinids are generally known to be restricted to specific geographical areas (e.g. archipelago or large bay), usually a few hundred kilometers in a straight line (Silva et al. 2008; Bearzi et al. 2011). The exception is the atypically large-sized delphinid killer whale (Orcinus orca) that had been described moving between areas distancing several thousand kilometers apart (Dahlheim et al. 2008; Durban and Pitman 2012). Here, we use long-term photographic-identification datasets of a medium-large sized delphinid, the short-finned pilot whale (Globicephala macrorhynchus), from two oceanic archipelagos of the North Atlantic to report a round-trip movement on a scale of thousands of kilometers.

The target species has a wide distribution from tropical to warm temperate waters, and on a global scale its conservation status is described as Data Deficient (Olson 2009). It is considered common throughout its range (Olson 2009), including the studied archipelagos of Madeira and the Azores (Silva et al. 2014; Alves et al. 2015). In Madeira, short-finned pilot whales are known to demonstrate varying patterns of occurrence, including residents, regular visitors, and transients, which may not be genetically isolated (Alves et al. 2013a). The presence of multiple populations of short-finned pilot whales, i.e. co-occurrence of insular and pelagic

* MARE-Marine and Environmental Sciences Centre, ARTDITI, Madeira, Portugal, CIIMAR-Madeira, Interdisciplinary Centre of Marine and Environmental Research of Madeira, Portugal. Corresponding author: filipe.alves@ciimarmadeira.org.

** University of Algarve, Portugal.

*** cE3c-Centre for Ecology, Evolution and Environmental Changes /Azorean Biodiversity Group, and Faculdade de Ciências e Tecnologia, University of Azores, Portugal.

- Nova Atlantis Foundation, Risso's Dolphin Research Center, Azores, Portugal. 


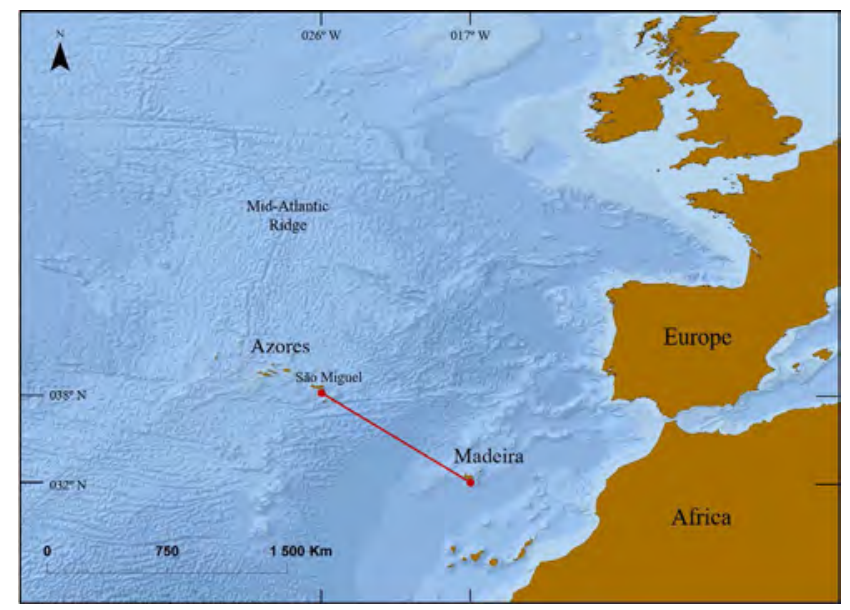

Figure 1. Location of the five socially related short-finned pilot whales (Delphinidae) photographed in the Azores and Madeira (solid circles). In the Azores, these animals were captured only twice during June 2015 at south of São Miguel Island. Whereas in Madeira, they were sighted regularly throughout the year between 2003 and 2015 mainly at south of Madeira Island. While the one-way distance covered at least $1000 \mathrm{~km}$ and lasted a maximum of 49 days, the round-trip movement $(\min .2000 \mathrm{~km}$ ) lasted a maximum of 4.5 months.

The straight line is merely indicative of the minimum migratory pathway.

animals, has been also recorded in the oceanic archipelagos of the Canaries and Hawai'i (Servidio 2014; Mahaffy et al. 2015). Especially in the Hawai'i, where the population structure of odontocetes have been extensively examined through photographic-identification, genetic analyses, and/or satellite tagging (Baird et al. 2015), several other (small to medium-large sized) delphinid species have been described to also form island-associated populations (Baird et al. 2008a,b, 2009, 2012; Aschettino et al. 2012; Martien et al. 2012, 2014, 2017; Hartman 2015a). According to Martien et al. (2017), those populations maintain some level of connectivity either through occasional dispersal or gene flow with larger pelagic populations. However, there is general lack of evidence of long-distance movements by small to medium-large sized island-associated or resident dolphins from its core/modal habitat. Here, we describe wide-ranging movements of socially related short-finned pilot whales exhibiting year-round site fidelity to an oceanic island, contributing to shed some light into the distributional and social ecology of this difficult to study animals.

\section{MATERIAL AND METHODS}

First, in order to assess wide-ranging movements of short-finned pilot whales, photographic-identification datasets from two archipelagos of the North Atlantic located at approximately $1000 \mathrm{~km}$ apart (figure 1) were compared. The dataset from 
Madeira was a photographic-identification catalogue comprised of 537 naturally marked individuals with known residency patterns, and was based on individual identifications collected on platforms of opportunity operating year-round between 2003 and 2015 mainly at the south of the Island. The dataset from the Azores was comprised of 156 opportunistic individual identifications collected in the archipelago of the Azores (mainly at the south of São Miguel Island), with irregular and nonrandom effort during the same period. The datasets are hosted at the Oceanic Observatory of Madeira and MONICET online platforms, respectively.

Second, information on the individuals that were found moving between both areas were analysed in order to better understand such movements. Information included data on the residency status, age class, sex, and on the temporal association patterning among them. The residency status was defined based on the dataset of individual-specific encounter (hereafter 'capture' [Chabanne et al. 2017]) histories, following Alves et al. (2013a). An ad-hoc calculation of the number of months the individuals were captured in relation to the total number of months with captures of short-finned pilot whales was used to help describing the residency pattern of these individuals. The age class was based on the comparison of the relative size of individuals and density of scars using photographs featuring multiple individuals as well as on field observations, according to descriptions by Yonekura et al. (1980) and Kasuya and Marsh (1984). On most cases, it was possible to infer sex due to being adults regularly (i.e. over multiple encounters) accompanied by small calves and/or by their small dorsal fins; as a sexually dimorphic species (Yonekura et al. 1980; Olson 2009).

The frequency of occurrence of the individuals per sampling occasion, i.e. how often these individuals were seen together, was used to obtain descriptive information on the associations of the animals concerned. However, due to the nature of the data (i.e. obtained from whale-watching platforms that spent a limited period of time with the animals, which consequently did not allow capturing the entire group in the majority of the photographic occasions), standardised lagged association rates (SLAR) were also used to help describing the temporal patterns in social relationships of these individuals (Whitehead 1995). SLAR can deal with data collected with non-regular effort (i.e. where not all animals were captured in each photographic occasion) (Whitehead 2008), as the case of our study. Encounters with only one photographic capture were excluded from the analysis. Sampling period was defined as day, and associations as individuals grouped within an encounter. Exponential models representing simulated social structures (Whitehead 1995) were fitted to the SLAR. The best fit model was chosen as that which minimised the Quasi Akaike Information Criterion (QAIC) (Whitehead 2008). SLAR were plotted on a logarithmic $\mathrm{x}$-axis time lag scale, since time differences between sampling periods ranged over an order of magnitude. To interpret SLAR we also considered the null rates, which were the values animals would have if associated randomly (see Whitehead [1995] for equations). The precision (SE) was estimated using the temporal jackknife method on each sampling period (Whitehead 2008). The limitations of modelling a dataset with a low number of individuals are mentioned in Discussion and in table 1 . All association analyses were performed with the compiled version of SOCPROG 2.7 (Whitehead 2009). 


\begin{tabular}{|c|c|c|c|}
\hline \multicolumn{4}{|c|}{$\begin{array}{l}\text { TABLE } 1 . \text { FIT OF SOCIAL SYSTEM MODELS TO THE STANDARDISED LAGGED ASSOCIA- } \\
\text { TION RATE (SLAR) FOR THE FIVE STUDIED INDIVIDUALS. } \tau \text { IS TIME LAG IN DAYS. MO- } \\
\text { DELS RANKED BY THE QUASI AKAIKE INFORMATION CRITERION (QAIC); THE LOWEST } \\
\text { (IN BOLD) INDICATES THE BEST-FITTING MODEL* }\end{array}$} \\
\hline DESCRIPTION OF MODEL & MODEL FORMULA & $\begin{array}{l}\text { NUMBER OF } \\
\text { PARAMETERS }\end{array}$ & QAIC \\
\hline Constant companions (CC) & 0.2 & 1 & 25897.83 \\
\hline Casual acquaintances (CA) & $0.19997 e^{(0.000000035886 . t)}$ & 2 & 25899.83 \\
\hline $\mathrm{CC}+\mathrm{CA}$ & $0.2-0.0000074067 e^{(-2.9239 \cdot \mathrm{t})}$ & 3 & 25901.83 \\
\hline Two levels of CA & $0.000075502 e^{(-1.3168 \cdot t)}+0.2 e^{(-0.0000000040339 \cdot t)}$ & 4 & 25903.83 \\
\hline \multicolumn{4}{|c|}{$\begin{array}{l}\text { * According to Burnham and Anderson (2002) (in References), a difference of up to two values in the QAIC between the } \\
\text { other model, indicates that the less favourable model may offers substantial support. In this case, the difference between } \\
\text { best model in the QAIC is of two values, which suggest that the second best model is near of offering some support. Yet, t1 } \\
\text { the small dataset (comprised of five individuals; which is a common number when analysing social structures of closely a } \\
\text { vertebrates [see Whitehead 2008, in References]) and by the non-dedicated effort, which may be insufficient to support } \\
\text { mathematical viewpoint. But from a biological approach, the model produced a clear horizontal line, which suggest constan } \\
\text { out the study period. This is supported by the descriptive analysis of these individuals' associations, which shows they we }\end{array}$} \\
\hline
\end{tabular}

\section{RESULTS}

Five adults, of which at least three are presumed to be females, were identified in both photographic datasets (figure 2). In the Azores, the five animals' capture histories are restricted to two occasions spaced shortly in time (10 days) and space (11 $\mathrm{km}$ ) off São Miguel Island. Whereas in Madeira, they belong to the main resident pod, having been photographically-identified on 86 occasions during 13 years, covering every year and all calendar months (maximum of nine months in a single year). The 86 occasions cover 55 months, out the 108 where photo-identification data of shortfinned pilot whales was collected. This indicates that these individuals were captured on $59.4 \%$ of the months that the target species was photographed in Madeira.

During 2015, the five animals were photographically-identified on several occasions from January to $14^{\text {th }}$ of April in Madeira, on the $2^{\text {nd }}$ and $12^{\text {th }}$ of June in the Azores, and again on several occasions from $28^{\text {th }}$ of August to December in Madeira. The one and two-way movements between their core habitat and the Azores, lasted a maximum (given that captures are a function of effort, i.e. the number of photographically-identified animals are dependent of the search effort) of 49 days and 4.5 months, respectively.

The descriptive approach to assess the association patterns of these individuals during the 86 occasions in Madeira shows that only one individual was captured during 27 occasions, two during 14, three during 22, four during 11, and five during 12. Associations of the five individuals were recorded across the entire study period. Each individual was captured on 43, 50, 39, 42, and 51 occasions (ESM 1). The social system model that best fits the curve of the temporal pattern in social relationships between the five individuals is described by the model with the constant companion hypothesis (figure 3, table 1). 


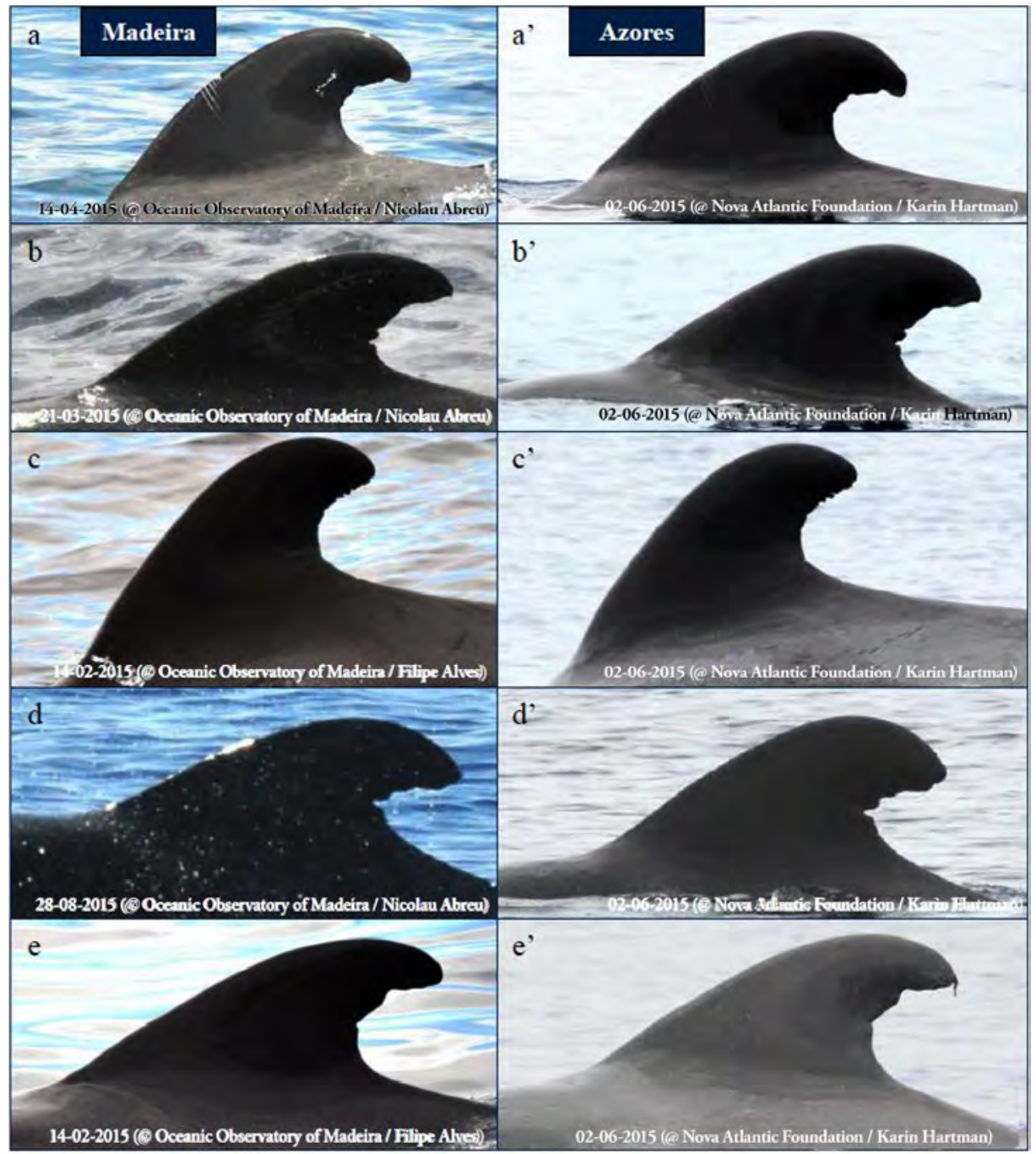

Figure 2. Photographic identification of the five individuals (IDs OOM_Gma089, OOM_ Gma112, OOM_Gma110, OOM_Gma002, OOM_Gma166, respectively from a-e) captured in the archipelagos of Madeira (Left, a-e) and Azores (right, a'- e') during 2015. The photographs $\mathrm{c}$ and e were inverted to facilitate comparison.

\section{DISCUSSION}

This study shows that five socially related short-finned pilot whales exhibiting strong site fidelity, made a round-trip movement of at least 2000 kilometers between the two most isolated archipelagos of the North Atlantic. To our best knowledge, 


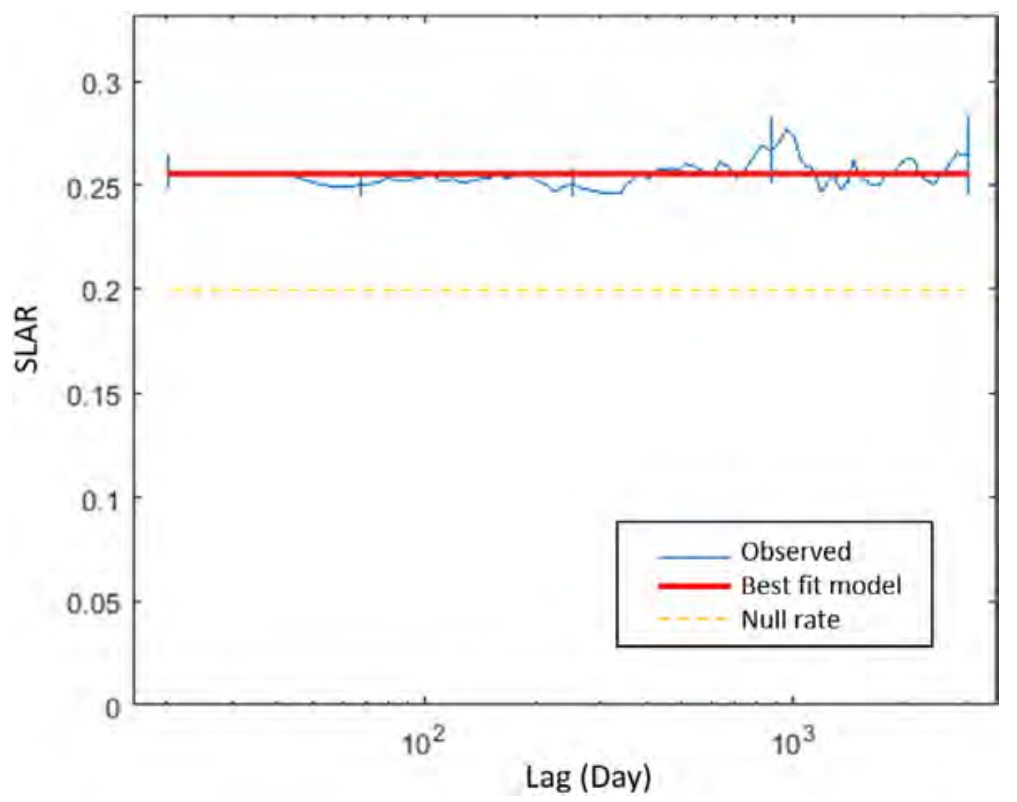

Figure 3. Standardized lagged association rate (SLAR) for the five studied individuals photographically captured in Madeira between 2003 and 2015, used to support the analysis of the descriptive association patterns. We used only high-quality images from encounters with more than one capture (from 57 days). Sampling period was defined as day, and associations as individuals grouped within an encounter. Vertical bars indicate SE calculated using the temporal jackknife method on each sampling period. The best fit model (based on the lowest QAIC) represents associations with constant companions $[\mathrm{g}(\tau)=0.2]$ (table 1 , which includes a discussion on the interpretation and selection of the best model). The null association rate represents the theoretical SLAR expected if individuals associated randomly.

apart from the killer whale, this constitutes an unprecedented wide-ranging movement for any resident or island-associated delphinid (at least from photographic-identification), thus providing new insights into the migratory ecology of delphinids.

The transience and the emigration and re-immigration of short-finned pilot whales into Madeiran waters (Alves et al. 2015) indicate wide-ranging movement of these animals, and demonstrate that the population under study uses a more extensive area than that surveyed. This is also supported by potential gene flow between transients and the 140 (95\% CI: 131-151) estimated island-associated animals (composed of three clans, each containing two to three matrilineal pods) for Madeira (Alves et al. 2013a, 2015); coincident with the low genetic variability found in other regions (Oremus et al. 2009; Van Cise et al. 2016). Although a more localised distribution and more predictable occurrence could be expected from the latter ecotype (animals with strong site fidelity), the movements documented in our study are not totally surprising. This is due to this species, as well as delphinids in 
general, being capable of ranging widely. Such capability is supported by the total distance travelled and/or the continuous movements monitored via satellite-linked telemetry in short-finned pilot whales off Florida (Well et al. 2013) and Hawai' $i$ (Abecassis et al. 2015), as well as in other delphinid species. Examples include the related congener species, the long-finned pilot whale (G. melas) (Nawojchik et al. 2003), the false killer whale (Pseudorca crassidens) (Baird et al. 2012; Palmer et al. 2017), the pigmy killer whale (Feresa attenuata) (Baird et al. 2011), or the killer whale (Dahlheim et al. 2008; Durban and Pitman 2012). Yet, none of the previous examples relate to animals with (known strong) site fidelity, contrary to what shown in our study.

The results also evidence a non-travelling period at the 'turning-point' in the Azores. This apparent stop (of at least 10 days in the same area) during the migration suggests that these movements were for breeding or feeding purposes. This is in agreement with previous studies on short-finned pilot whales carried out in the neighbouring archipelagos (of Madeira and the Canaries), where mating and foraging activity has been suggested to occur (Heimlich-Boran 1993; de Soto et al. 2008; Alves et al. 2013a,b; Servidio 2014). Apart from those two main obvious purposes contributing to migration of marine predators, others may include competition, or even climate change (Greenwood 1980; Stevick et al. 2002). The recorded movements contrast the rapid and non-stop round-trip movements made by Antarctic killer whales to subtropical waters that are probably related to physiological maintenance migrations, i.e. to allow skin regeneration without the high cost of heat loss (Durban and Pitman 2012).

The descriptive analysis of the association patterns shows that the five individuals were recorded together on multiple occasions during the entire study period. The remaining occasions where not all the individuals were captured could be related to the fact of having collected the data onboard platforms of opportunity, which reduced the chances of capturing the entire group. The SLAR analysis support that the five individuals are constant companions, indicating a social structure with long-lasting relationships. Yet, SLAR should be interpreted with caution given the dataset used in the analysis (with few individuals and collected with non-dedicated effort). This limitation could explain the difference of two values in the QAIC between the best and the second best model (table 1), which is near the limit of offering substantial support (Burnham and Anderson 2002). Nevertheless, modelling should also be interpreted from a biological viewpoint rather than a merely mathematical one (e.g. Allman and Rhodes 2004). And in our case, the straight horizontal SLAR line seems to support the best fit model of constant companions. Moreover, the five individuals belong to the main pod (R4) inhabiting Madeiran waters, which is composed of nine constant and well-marked companions (Alves $e t$ al. 2013a). Although no inferences can be made about the remaining four individuals in pod R4, which were not photographically-identified during the 4.5 month period, the long distances travelled by (at least some) members of a cohesive social unit reinforce that pilot whales display a strong social pattern (e.g. de Stephanis et al. 2008; Alves et al. 2013a, Mahaffy et al. 2015). 
As conclusion, our findings suggest that describing residency status in delphinids needs to be done with caution, even in animals exhibiting long-term site fidelity. Finally, the present study highlights the importance of open-access photographic-identification catalogues (e.g. online), and broadens our understanding on the geographical population structure and perception of home ranges of these animals.

Recibido: November de 2017, ACEptado: January de 2018

\section{ACKNOWLEDGMENTS}

We thank the whale-watching operators Ventura | Nature emotions, H2O-Madeira, and LobosOnda in Madeira, and Picos de Aventura, Terra Azul, Horta Cetáceos, Sea Colors, Ocean Emotion, and Futurismo in Azores, citizen scientists, and volunteers, for help with the field work and contributing with photographic data. This research has made use of data provided in the online MONICET platform (www.monicet.net), which is supported by the Azorean Biodiversity Group / cE3c - Centre for Ecology, Evolution and Environmental Changes, and the Nova Atlantis Foundation. This study was partially supported by the Oceanic Observatory of Madeira throughout the project M1420-01-0145-FEDER-000001-OOM, and by ARDITI - Madeira's Regional Agency for the Development of Research, Technology and Innovation, for funding the FA and AD postdoctoral grants throughout the Project Madeira M1420-09-5369-FSE-000001. We acknowledge Gustavo Silva for help with the creation of the map, Lisa T. Ballance for providing valuable comments on a previous draft of this paper, and Jonathan Greenslade for reviewing the writing. We have no competing interests, and the data used in this study are presented in the ESM 3.

\section{AUTHORS' CONTRIBUTION}

Conceptualization: FA.

Methodology and field work: all authors.

Data analysis: FA and AA.

Original draft: FA.

Review and edition of the final draft: all authors. 


\section{REFERENCES}

Abecassis, M., Polovina, J., Baird, R.W., Copeland, A., Drazen, J.C., Domokos, R., Oleson, E., Jia, Y., Schorr, G.S., Webster, D.L. and Andrews, R.D. 2015. Characterizing a foraging hotspot for short-finned pilot whales and Blainville's beaked whales located off the west side of Hawai'i Island by using tagging and oceanographic data. PLoS ONE 10, e0142628.

Allman, E.S. and Rhodes, J.A. 2004. Mathematical Models in Biology: An Introduction. Cambridge University Press, 386p.

Alves, F., Quérouil, S., Dinis, A., Nicolau, C., Ribeiro, C., Freitas, L., Kaufmann, M. and Fortuna, C. 2013a. Population structure of short-finned pilot whales in the oceanic archipelago of Madeira based on photo-identification and genetic analyses: Implications for conservation. Aquat. Conserv.: Mar. Freshw. Ecosyst. 23, 758-776.

Alves, F., Dinis, A., Ribeiro, C., Nicolau, C., Kaufmann, M., Fortuna, C. and Freitas, L. 2013b. Daytime dive characteristics from six short-finned pilot whales Globicephala macrorhynchus off Madeira Island. Arquipelago - Life Mar. Sci. 31, 1-8.

Alves, F., Dinis, A., Nicolau, C., Ribeiro, C., Kaufmann, M., Fortuna, C. and Freitas, L. 2015. Survival and abundance of short-finned pilot whales in the archipelago of Madeira, NE Atlantic. Mar. Mamm. Sci. 31, 106-121.

Aschettino, J.M., Baird, R.W., McSweeney, D.J., Webster, D.L., Schorr, G.S., Huggins, J.L., Martien, K.K., Mahaffy, S.D. and West, K.L. 2012. Population structure of melon-headed whales (Peponocephala electra) in the Hawaiian Archipelago: evidence of multiple populations based on photo-identification. Mar. Mamm. Sci. 28, 666-689.

Baird, R.W., Webster, D.L., Mahaffy, S.D., McSweeney, D.J., Schorr, G.S. and Ligon, A.D. 2008a. Site fidelity and association patterns in a deep-water dolphin: Rough-toothed dolphins (Steno bredanensis) in the Hawaiian Archipelago. Mar. Mamm. Sci. 24, 535-553.

Baird, R.W., Gorgone, A.M., McSweeney, D.J., Webster, D.L, Salden, D.R., Deakos, M.H., Ligon, A.D., Schorr, G.S., Barlow, J. and Mahaffy, S.D. 2008b. False killer whales (Pseudorca crassidens) around the main Hawaiian Islands: Long-term site fidelity, inter-island movements, and association patterns. Mar. Mamm. Sci. 24, 591-612.

Baird, R.W., Gorgone, A.M., McSweeney, D.J., Ligon, A.D., Deakos, M.H., Webster, D.L., Schorr, G.S., Martien K.K., Salden, D.R. and Mahaffy, S.D. 2009. Population structure of island-associated dolphins: Evidence from photo-identification of common bottlenose dolphins (Tursiops truncatus) in the main Hawaiian Islands. Mar. Mamm. Sci. 25, 251-274.

Baird, R.W., Schorr, G.S., Webster, D.L., McSweeney, D.J., Hanson, M.B. and Andrews, R.D. 2011. Movements of two satellite-tagged pygmy killer whales (Feresa attenuata) off the island of Hawai'i. Mar. Mamm. Sci. 27, E332-E337.

Baird, R.W., Hanson, M.B., Schorr, G.S., Webster, D.L., McSweeney, D.J., Gorgone, A.M., Mahaffy, S.D., Holzer, D.M., Oleson, E.M. and Andrews, R.D. 2012. Range and primary habitats of Hawaiian insular false killer whales: informing determination of critical habitat. Endang. Species Res. 18, 47-61.

Baird, R.W., Cholewiak, D., Webster, D.L., Schorr, G.S., Mahaffy, S.D., Curtice, C., HarRISON, J. and VAN PARIJS, S.M. 2015. Biologically important areas for cetaceans within U.S. Waters - Hawai'i Region. Aquat. Mamm. 41, 54-64. 
Bearzi, G., Bonizzoni, S. and Gonzalvo, J. 2011. Mid-distance movements of common bottlenose dolphins in the coastal waters of Greece. J. Ethol. 29, 369-374.

Burnham, K.P. and Anderson, D.R. 2002. Model selection and multimodel inference: a practical information-theoretic approach. New York, Springer-Verlag, 488p.

Chabanne, D.B.H., Pollock, K.H., Finn, H. and Bejder, L. 2017. Applying the multistate capture-recapture robust design to characterize metapopulation structure. Methods Ecol. Evol. 8, 1547-1557.

Dahlheim, M.E., Schulman-Janiger, A., Black, N., Ternullo, R., Ellifrit, D. and Balcomb III, K.C. 2008. Eastern temperate North Pacific offshore killer whales (Orcinus orca): occurrence, movements, and insights into feeding ecology. Mar. Mamm. Sci. 24, 719-729.

de Soto, N.A., Johnson, M.P., Madsen, P.T., Díaz, F., Domínguez, I., Brito, A. and Tyack, P. 2008. Cheetahs of the deep sea: deep foraging sprints in short-finned pilot whales off Tenerife (Canary Islands). J. Animal Ecol. 77, 936-947.

de Stephanis, R., Verborgh, P., Pérez, S., Esteban, R., Minvielle-Sebastia, L. and Guinet, C. 2008. Long-term social structure of long-finned pilot whales (Globicephala melas) in the Strait of Gibraltar. Acta Ethol. 11, 81-94.

Durban, J.W. and Pitman, R.L. 2012. Antarctic killer whales make rapid, round-trip movements to subtropical waters: evidence for physiological maintenance migrations? Biol. Lett. 8, 274-277.

Foote, A.D., Similä, T., Víkingsson, G.A. and Stevick, P.T. 2010. Movement, site fidelity and connectivity in a top marine predator, the killer whale. Evol. Ecol. 24, 803-814.

Greenwood, P.J. 1980. Mating systems, philopatry and dispersal in birds and mammals. Anim. Behav. 28, 1140-1162.

Heimlich-Boran, J.R. 1993. Social organization of the short-finned pilot whale, Globicephala macrorhynchus, with special reference to the comparative social ecology of delphinids. $\mathrm{PhD}$ thesis, Cambridge University, England.

Kasuya, T. and Marsh, H. 1984. Life history and reproductive biology of the short-finned pilot whale, Globicephala macrorhynchus, off the Pacific coast of Japan. Rep. Int. Whal. Commn. (Sp. Issue) 6, 259-310.

Mahaffy, S.D., Baird, R.W., McSweeney, D.J., Webster, D.L. and Schorr, G.S. 2015. High site fidelity, strong associations, and long-term bonds: Short-finned pilot whales off the island of Hawai'i. Mar. Mamm. Sci. 31, 1427-1451.

Martien, K.K., Baird, R.W., Hedrick, N.M., Gorgone, A.M., Thieleking, J.L., McSweeney, D.J., Robertson, K.M. and Webster, D.L. 2012. Population structure of island-associated dolphins: evidence from mitochondrial and microsatellite markers for common bottlenose dolphins (Tursiops truncatus) around the main Hawaiian Islands. Mar. Mamm. Sci. 28, E208-E232.

Martien, K.K., Chivers, S.J., Baird, R.W., Archer, F.I., Gorgone, A.M., Hancock-Hanser, B.L., Mattila, D., McSweeney, D.J., Oleson, E.M., Palmer, C., Pease, V.L., Robertson, K.M., Schorr, G.S., Schultz, M.B., Webster, D.L. and Taylor, B.L. 2014. Nuclear and mitochondrial patterns of population structure in North Pacific false killer whales (Pseudorca crassidens). J. Hered. 105, 611-626.

Martien, K.K., Hancock-Hanser, B.L., Baird, R.W., Kiszka, J.J., Aschettino, J.M., Oremus, M. and Hill, M.C. 2017. Unexpected patterns of global population structure in melon-headed whales Peponocephala electra. Mar. Ecol. Prog. Ser. 577, 205-220. 
Nawojchik, R., Aubin, D.J.St. and Johnson, A. 2003. Movements and dive behavior of two stranded, rehabilitated long-finned pilot whales (Globicephala melas) in the northwest Atlantic. Mar. Mamm. Sci. 19, 232-239.

Olson, P. 2009. Pilot whales Globicephala melas and G. macrorhynchus. In Encyclopedia of marine mammals, $2^{\text {nd }}$ edition (eds W.F. Perrin, B. Würsig, J.G.M. Thewissen), pp. 847-852. Amsterdam: Academic Press.

Oremus, M., Gales, R., Dalebout, M.L., Funahashi, N., Endo, T., Kage, T., Steel, D. and BAKER, S.C. 2009. Worldwide mitochondrial DNA diversity and phylogeography of pilot whales (Globicephala spp.). Biol. J. Linnean. Soc. 98, 729-744.

Palmer, C., Baird, R.W., Webster, D.L., Edwards, A.C., Patterson, R., Withers, A., Withers, E., Groom, R. and Woinarski, J.C.Z. 2017. A preliminary study of the movement patterns of false killer whales (Pseudorca crassidens) in coastal and pelagic waters of the Northern Territory, Australia. Mar. Freshw. Res. 68, 1726-1733.

Robbins, J., Rosa, L.D., Allen, J.M., Mattila, D.K., Secchi, E.R., Friedlaender, A.S., Stevick, P.T., Nowacek, D.P. and Steel, D. 2011. Return movement of a humpback whale between the Antarctic Peninsula and American Samoa: a seasonal migration record. Endang. Species Res. 13, 117-121.

Servidio, A. 2014. Distribution, social structure and habitat use of short-finned pilot whale, Globicephala macrorhynchus, in the Canary Islands. PhD thesis, University of St. Andrews, Scotland.

Silva, M.A., Prieto, R., Magalhães, S., Seabra, M.I., Santos, R.S., Hammond, P.S. 2008. Ranging patterns of bottlenose dolphins living in oceanic waters: implications for population structure. Mar. Biol. 156, 179-192.

Silva, M.A., Prieto, R., Cascão, I., Seabra, M.I., Machete, M., Baumgartner, M.F. and SANTOS, R.S. 2014. Spatial and temporal distribution of cetaceans in the mid-Atlantic waters around the Azores. Mar. Biol. Res. 10, 123-137.

Stevick, P.T., McConnell, B.J. and Hammond, P.S. 2002. Patterns of movement. In Marine mammal biology: an evolutionary approach (ed A.R. Hoelzel), pp. 185-216. Oxford, Blackwell Publishing.

Stone, G., Florez-Gonzalez, L. and Katona, S. 1990. Whale migration record. Nature 346, 705.

Van Cise, A.M., Morin, P.A., Baird, R.W., Lang, A.R., Robertson, K.M., Chivers, S.J., Brownell, R.L. and Martien, K.K. 2016. Redrawing the map: mtDNA provides new insight into the distribution and diversity of short-finned pilot whales in the Pacific Ocean. Mar. Mamm. Sci. 32, 1177-1199.

Wells, R.S., Fougeres, E.M., Cooper, A.G., Stevens, R.O., Brodsky, M., Lingenfelser, R., Dold, C. and Douglas, D.C. 2013. Movements and dive patterns of short-finned pilot whales (Globicephala macrorhynchus) released from a mass stranding in the Florida Keys. Aquat. Mamm. 39, 61-72.

Whitehead, H. 1995. Investigating structure and temporal scale in social organizations using identified individuals. Behav. Ecol. 6, 199-208.

Whitehead, H. 2001. Analysis of animal movement using opportunistic individual-identifications: application to sperm whales. Ecology 82, 1417-1432.

Whitehead, H. 2008. Analyzing animal societies: quantitative methods for vertebrate social analysis. Chicago, USA: University of Chicago Press, 336p. 
Whitehead, H. 2009. SOCPROG programs: analyzing animal social structures. Behav. Ecol. Sociobiol. 63, 765-778.

Whitehead, H., Coakes, A., Jaquet, N. and Lusseau, S. 2008. Movements of sperm whales in the tropical Pacific. Mar. Ecol. Prog. Ser. 361, 291-300.

Wilson, B., Reid, R.J., Grellier, K., Thompson, P.M. and Hammond, P.S. 2004. Considering the temporal when managing the spatial: a population range expansion impacts protected areas-based management for bottlenose dolphins. Animal Conserv. 7, 331-338.

WürsIG, B. and WÜrsIG, M. 1977. The photographic determination of group size, composition, and stability of coastal porpoises (Tursiops truncatus). Science 198, 755-756.

Yonekura, M., Matsui, S. and Kasuya, T. 1980. On the external characters of Globicephala macrorhynchus off Taiji, Pacific coast of Japan. Sci. Rep. Whales Res. Inst. 32, 67-95. 
